\title{
Fascism, Comedy, and Weak Commitments \\ in Nancy Mitford's Wigs on the Green
}

\author{
Eliza Murphy \\ School of Humanities, University of Tasmania, Hobart, Australia \\ eliza.murphy@utas.edu.au
}

\section{Notes on Contributor}

Eliza Murphy is a $\mathrm{PhD}$ candidate in the School of Humanities at the University of Tasmania. Her doctoral research explores the role and representation of parties in comic novels of the interwar period, with a focus on the works of E. F. Benson, Stella Gibbons, Nancy Mitford, and Evelyn Waugh. She has published in the Journal of Festive Studies (with Naomi Milthorpe). 


\title{
Fascism, Comedy, and Weak Commitments in Nancy Mitford's Wigs on the Green
}

\begin{abstract}
Occupying an ambiguous position in relation to the literary movements of the twentieth century, British writer Nancy Mitford (1904-1973) is most well-known for her postwar novels, The Pursuit of Love (1945) and Love in a Cold Climate (1949). However, her interwar novels published in the early years of her writing career offer the potential for fruitful readings. This article takes as its focus Mitford's 1935 novel Wigs on the Green, a romantic comedy revolving around a fascist pageant play. Through comedy, the novel critiques the aristocracy's engagement with radical politics, which it interprets as an effort to restore traditional ideals of Englishness. Wigs on the Green, like many of Mitford's novels, is characterized in its form and content by weak commitments which serve to generate the novel's laughter and critique: from the characters' naïve acceptance of fascism to the novel's subversion of the conventions of the romantic comedy. Wigs on the Green's preoccupation with weak commitments is best revealed through a reading that positions Mitford as an "intermodern" writer, a framework I argue is attuned to weakness. Mitford's novel thus reveals the usefulness of intermodernism for reading and recovering women's comedy writing of the interwar years.
\end{abstract}

\section{Keywords}

Nancy Mitford; fascism; comedy; intermodernism; Englishness

On 21 June 1935, Nancy Mitford wrote a panicked letter to her younger sister Unity, worried that the content of her latest novel, Wigs on the Green, would offend her. "So now don't get together with Nardie \& ban me forever," she writes, "or I shall die."1 Mitford's concern was justified: the content of the novel, a romantic comedy that lampoons both the aristocracy and fascism, was certainly contentious. By 1935, both Unity and Nardie (a family nickname for one of Mitford's other siblings, Diana) had dedicated themselves to the fascist movement. Diana had abandoned her high-profile society marriage to become the mistress of Sir Oswald Mosley, the leader of the British Union of Fascists (BUF), and Unity had several extended stays in Nazi Germany throughout the 1930s. In the same letter, Mitford assures Unity that she has removed "some absolutely wonderful jokes" in order to appease her. ${ }^{2}$ Indeed, Mitford had already self-censored the book considerably. In an earlier letter, she 
confirmed "all reference to the F" — the Führer — had been omitted, ${ }^{3}$ and objections from Diana and Mosley meant "nearly 3 chapters \& a lot of paragraphs" which "directly related to Captain Jack," the novel's version of Mosley, were scrapped entirely. ${ }^{4}$ But Mitford's attempts to mask her targets in the finished product are half-hearted at best. Fascism becomes "Social Unionism," and Mosley’s followers, the Blackshirts, are the "Union Jackshirts."5 Unity — a dedicated and somewhat fanatic admirer and defender of Hitler — is the inspiration for the novel's heroine.

Mitford maintained to Diana that Wigs on the Green was as a whole "very pro-

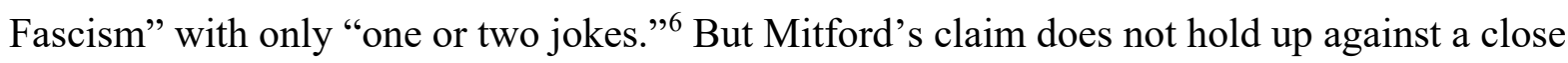
reading of the text. The bulk of the novel's action unfolds in the village of Chalford, where Noel Foster and Jasper Aspect have travelled in the hope of marrying one of the richest young women in the country, Eugenia Malmains. They quickly learn, however, that Eugenia is a devoted supporter of Social Unionism. Over the course of the novel, Eugenia recruits Noel and Jasper - along with two wealthy women also visiting the village, Poppy St. Julien and Marjorie Merrith — to the movement. The novel culminates with the group organizing a pageant play, intended as a re-enactment of a royal visit to Chalford in the 1700 s, but the play quickly devolves into a chaotic battle between the Social Unionists and their sworn enemies, the Pacifists. Mitford treats Social Unionism mockingly: Eugenia is an exaggerated figure, who preaches in the village green on an upturned bathtub and greets everyone with "Hail!"; the Union Jackshirts, meanwhile, intimidate their enemies by flinging them into duck ponds. It is not surprising that once the book was published, Diana was extremely offended, and the relationship between the sisters cooled considerably. ${ }^{8}$

Reviewing Wigs on the Green in the Sunday Times upon its release, Ralph Straus described the novel as "a delicious piece of buffoonery which can hardly be read without chuckles." ${ }^{\prime 9}$ It became more difficult to praise the novel for its humor, however, after the 
events of the Second World War, and Mitford refused to have the novel reprinted in her lifetime. When her publisher Hamish Hamilton offered to re-release her prewar novels in 1951, Mitford felt "[t]oo much has happened for jokes about Nazis to be regarded as funny or as anything but the worst of taste." 10 The pleasures of reading Wigs on the Green in the twenty-first century are certainly troubling. For contemporary readers, it is a novel where- to borrow the words of Lauren Berlant and Sianne Ngai- " "the funny is always tripping over the not funny." 11 There is considerable tension between laughing at how Mitford shamelessly sends up extremist politics while being highly conscious of the serious events caused by fascism and Nazism in the Second World War.

Most scholarship on the intersection between fascism and early twentieth-century writing focuses on all too familiar names associated with high modernism: Eliot, Lewis, Pound. ${ }^{12}$ Feminist scholars, such as Jessica Berman, Erin G. Carlston, Laura Frost, and Merry M. Pawlowski, have extended this discussion to modernist women writers. ${ }^{13}$ As Judy Suh argues, much modernist-adjacent and middlebrow writing of the period (often flavored by comedy or satire) is also centrally concerned with the influence of far-right politics upon Britain. ${ }^{14}$ Mitford was not alone in poking fun at Mosley and British fascism in the interwar years, as P. G. Wodehouse's Sir Roderick Spode (The Code of the Woosters) and Aldous Huxley's partial portrait in the character of Everard Webley (Point Counter Point) illustrate. But what separates Mitford's work from that of Wodehouse and Huxley is her use of "weak commitments" to generate the novel's laughter and critique: that is, the idea that one could attach themselves to someone or something without having to follow through with its consequences. ${ }^{15}$ Weak commitments manifest in both the novel's form and content. Mitford's characters - flippant, textually flat, and lacking in interiority — are weakly committed to politics, history, and each other. These weak commitments are intimately tied to Mitford's 
own weak commitment to adhering to the conventions of the comic novel. Together, these weak commitments advance Mitford's critique of fascism.

This article argues that Wigs on the Green's preoccupation with weak commitmentsboth in terms of its politics and comedy — is best revealed through a reading that positions Mitford as an "intermodern" writer, a concept coined by Kristin Bluemel that seeks to accommodate more writers of the 1930s and 1940s into literary histories of the twentieth century. ${ }^{16}$ Mitford's novel critiques fascism — and indeed all extremist politics — and in doing so, it also critiques the aristocracy, and especially aristocratic women, for their willingness to commit to fascism in their bid to restore traditional ideals of Englishness without first questioning fascism's more radical ideologies. Mitford's novel thus reveals the usefulness of intermodernism as a tool for reading and recovering women's comedy writing of the interwar years.

\section{Intermodernism and Weak Commitments}

My understanding of weakness aligns with that of Paul K. Saint-Amour, who calls for a consideration of "weakness as a condition endowed with traits and possibilities of its own."17 Weakness, then, can lead to strength and vitality. It is for this reason that Saint-Amour argues that modernism's tendency towards weak definitions and theorizations has led to the potency of the field as a whole. ${ }^{18}$ But Saint-Amour offers little commentary on how other critical terms for understanding twentieth-century writing, such as intermodernism, figure into the weak-yet-strong new modernist studies. Intermodernism, I would argue, has always been interested in weakness: through its own refusal to subsume works under the ever-expanding label of modernism and its impulse towards writers we might think of as weak (that is, not avant-garde) — the middlebrow, the minor, the popular. By creating a space for scholars to foster critical discussions of writers "whose work and working conditions were different from 
or eccentric to those of the modernists," 19 intermodernism at its very core is fundamentally concerned with locating, and finding strength in, weakness.

At first glance, intermodernism suggests an alignment with the interwar period through its prefix, appearing to fit within what Saint-Amour calls the "standard model" of history, which "favors linear, unidirectional narratives," and historical periods "that communicate minimally with one another." ${ }^{20}$ But while intermodernism certainly values historicization, ${ }^{21}$ it also refutes the neat and homogenizing impulses of both the new modernist studies and the interwar as an historical period. In its very name, intermodernism reveals its own weak and tactical commitment to modernism: it simultaneously relies on and critiques modernism's strength. ${ }^{22}$ Moreover, by going "beyond conceptions of periodicity" through its interest in writing produced across the early twentieth-century (encompassing wartime, the interwar, and the postwar), ${ }^{23}$ intermodernism, like Saint-Amour's notion of a "perpetual interwar," critically interrogates the relationship between historical periods and their works, enriching our accounts of twentieth-century literary history. ${ }^{24}$

For literary historians, intermodernism is a tool for recovery, bringing attention to writers left out of traditional discussions of modernism. ${ }^{25}$ As a critical term that "grows out of and assumes continuing investment in feminist inquiry, ${ }^{, 26}$ intermodernism is also a tool for feminist recovery, offering means to encounter women writers of the 1930s and 1940s who are frequently designated as middlebrow and thus omitted from the vertical expansion of new modernist studies described by Douglas Mao and Rebecca L. Walkowitz. ${ }^{27}$ As Faye Hammill argues, the debate over whether certain authors are modernist or middlebrow is a circular one that leads to little productivity and innovation. ${ }^{28}$ But it is evident that new modernist studies, at least in the study of Anglophone authors, has only been able to co-opt a certain type of writing into its canon, leaving behind writers who do not fit so readily into these frameworks. As Bluemel and Phyllis Lassner rightly (and boldly) assert, many women writers of the 1930s 
and 1940s "do not need to be rescued [...] by modernism." ${ }^{29}$ Intermodernism, then, is also a productive concept for scholars who themselves are weakly committed to modernism: those who work on minor or marginal writers but feel uncomfortable labelling them as modernist. In particular, intermodernism's explicitly feminist ethos allows for the recuperation of women's comic writing of the twentieth century, an area Sophie Blanch identifies as being neglected in scholarship as a consequence of the academic project to "ensure that women's contributions to Modernism are taken 'seriously." ${ }^{30}$ Kate Macdonald similarly argues that comic fiction is perceived as "not academically respectable" unless written by canonical figures "who transcend genre and can lend greatness to their humour." 31 These assertions leave the "comic, female, middlebrow novelist," as Erica Brown dryly observes, "to be damned three times over." ${ }^{32}$ With its emphasis on divergent forms and ideas to those typically understood as modernist, intermodernism opens avenues not just for the recovery of women comic novelists, but also for the study of twentieth-century comedy itself: studies of modernism and humor overwhelmingly place their emphasis on modes conventionally thought of as formally experimental, such as satire. ${ }^{33}$

Mitford, whose comic novels were written and published across the interwar, war, and postwar periods, is an ideal figure to read as an intermodern writer. Her best-known works remain those published in the years immediately after the Second World War: The Pursuit of Love (1945) and Love in a Cold Climate (1949). Her interwar novels have received little scholarly attention and are generally viewed as inferior when compared to her postwar titles. Even Selina Hastings, Mitford's biographer, characterizes her early works as being "bright, brittle, [and] essentially ephemeral." ${ }^{34}$ Mitford's literary contributions are further maligned by what Julie Gottlieb describes as the "Mitford-sisters industry" in popular history publishing. ${ }^{35}$ While lacking in some of the finesse that her later works demonstrate, Mitford's novels of the thirties-Highland Fling (1931), Christmas Pudding (1932), and Wigs on the 
Green - offer the potential for fruitful readings. Mitford's early novels communicate many of the same concerns as The Pursuit of Love and Love in a Cold Climate: Englishness, love, marriage, the decline of the aristocracy, and tradition versus modernity. Documenting the pursuits of a generation old enough to remember the First World War, but too young to participate in the war effort, these texts reveal the complexities of interwar society and sociability, adding layers to a period in literary history that male writers, such as the Auden Generation, frequently dominate. By viewing Mitford's novels as intermodern, it is evident that her penchant for weak commitments enhances, rather than detracts from, her comic critique.

\section{"The great houses of England [...] stand empty": Fascism and Englishness}

Wigs on the Green establishes its concern with the relationships between fascism, Englishness, tradition, and modernity at its outset when Noel and Jasper first encounter Eugenia giving an impassioned speech on Chalford's village green. The focus of her speech is the degradation of modern society:

Respect for parents, love of the home, veneration of the marriage tie, are all at a discount in England today, society is rotten with vice, selfishness, and indolence. The rich have betrayed their trust, preferring the fetid atmosphere of cocktail-bars and night-clubs to the sanity of a useful country life. The great houses of England, one of her most envied attributes, stand empty - why? Because the great families of England herd together in luxury flats and spend their patrimony in the divorce courts. ${ }^{36}$

In Eugenia's eyes, the modern state of England is a disgrace due to the decay of traditional values: the only way for progress is a return to the past, a key element of Mosley's vision for a fascist Britain. Eugenia's speech also immediately links the aristocracy to these concerns, as they are the "great families" who own these vast country estates. Mitford was particularly interested in the ways her own class, the aristocracy, responded to and embraced fascist ideas. The novel's main characters are aristocratic, and almost all of them convert to Social Unionism over the course of the novel. The aristocratic involvement with the BUF itself in 
the 1930s was relatively minor, ${ }^{37}$ but as Suh notes, many aristocrats had broader fascist sympathies because they believed it offered a way to "sustain authentic forms of Englishness," including the class hierarchies that benefited them so greatly. ${ }^{38}$ Mosley was an "aristocratic rebel" who turned towards fascism to combat the decay of his class. ${ }^{39}$ His family's ancestral estate had been sold in the early 1920s, and Mosley wanted to restore the feudal ideals of his childhood, a view that resounded with others who had faced (or were facing) a similar situation. ${ }^{40}$ Much in the same way, Eugenia's speech immediately resonates with Jasper, who comments that while she is a "lunatic," she is "not stupid." 41 The ideas within the speech - a decline in traditional values, the abandoned country house, the deterioration of the aristocracy—reflect and document Jasper's concerns.

By setting the action in the village of Chalford, Mitford connects the aristocratic sympathies for fascism to the interwar yearning for a return to pastoral and traditional forms of Englishness. Bluemel points to the country landscape as being a "site of origins or identity" for intermodern writers. ${ }^{42}$ Mitford herself grew up in the country, and the rural setting of Wigs on the Green is central to a reading of the novel as a critique of fascism. The fictional village of Chalford is in the Cotswolds, an area which interwar rural texts frequently imagined as an idealized version of England. ${ }^{43}$ The image of a green and idyllic English rural landscape was central to ideas of national identity prior to and during the First World War, but was under siege between the wars due to disorganized modernization. ${ }^{44}$ Fascism, with its promise of logical (and traditional) order, offered a means to reverse this chaos.

Mitford's interest in the relationship between the aristocracy and fascism, however, is not just confined to England. Julie V. Gottlieb has highlighted that the English aristocratic interest in fascism based itself on its international versions-Mussolini's Italy, Hitler's Germany—rather than its domestic iteration. ${ }^{45}$ These dictatorships carried "an aura of glamour" for certain sections of high society. ${ }^{46}$ Mitford mostly gleaned her knowledge of 
fascism from Diana and Unity, who were both frequent visitors to Germany in the 1930s. This may explain why Mitford frequently conflates British Fascism and German Nazism in Wigs on the Green, despite their differences in policy and principle. The novel, then, is not just a critique of the BUF, but of fascism as an ideology more broadly.

Mitford's impressions of fascism, however, were not solely based upon observing her sisters: she briefly entertained the idea of fascism herself. Along with her husband, Peter Rodd, she joined the BUF as a member for a few months in 1934, although her dedication to the cause is questionable, as it was during this time that she began writing Wigs on the Green. The violent events of the BUF's Olympia rally in June 1934 marked the moment when Mitford began to find Diana and Unity's extremism particularly objectionable. Importantly, Mitford soon positioned herself not just against fascist extremism, but all political extremism. The unwavering belief that extremists had in their politics went against Mitford's philosophy that "nothing in life should be taken too seriously." ${ }^{47}$ This kind of suspicion about political ideology — of any kind, not just fascism — is a common feature in intermodern women's writing of the 1930 s and 40 s. $^{48}$

Through the depiction of Eugenia, Wigs on the Green critiques overzealous commitments to politics, as Mitford denies the reader any chance of sympathizing with Eugenia's views by turning her into a comic figure. Eugenia's lack of maturity continually undercuts her ardent passion for Social Unionism and Captain Jack. Only seventeen years old, she is child-like in many ways: she wears an "ill-fitting" skirt with "no stockings," and her shoes are "threadbare." 49 The only item in good condition is the belt she wears, which carries a "large bright dagger." 50 She is fond of chocolate bars from the village shop, signs letters with drawings of swastikas and skull and crossbones, and enjoys snapping her fingers in triumph "but as her hands were soft and babyish she seldom achieved a satisfactory crack." ${ }^{51}$ Her political aspirations and her vision for a "glorious Britain" 52 jar against her 
characterization as an untidy, young girl: Mitford parses Eugenia's radicalism as naïve immaturity rather than considered endeavor.

Eugenia is not the only negative portrayal of a fascist follower, but she is the only character who displays an earnest, whole-hearted commitment in the novel, acting to further emphasize the glibness of Chalford's visitors. The novel positions the characters who become affiliated with Social Unionism over the course of the novel as inherently flawed, shown to become Union Jackshirts without any sustained consideration. The first recruits, Noel and Jasper, only join the movement as a means of pursuing Eugenia romantically. While Noel initially expresses doubts about Social Unionism, Eugenia coerces him into joining without having any of his concerns resolved. Membership requires a fee of ninepence and a "promise that you will obey the Captain in all things," but Noel immediately questions this absolute dedication: "[h]e might want me to do something very peculiar, mightn't he?"53 A threat of violence from Eugenia, however, immediately resolves any hesitation. Others are attracted to the lighter aspects of Social Unionism. Mr Wilkins, Marjorie's love interest, tells Eugenia that he will join the party with "pleasure," on the proviso that they are "against foreigners and the League of Nations." ${ }^{54}$ Eugenia, then, is the most dedicated to Social Unionism: for all her success in converting the others, none ever exhibits the same level of fanaticism or enthusiasm for the movement. For example, when the Union Jackshirts' headquarters burn to the ground in an arson attack, Eugenia is out for blood, but the others quickly pacify her threats of retaliatory violence. Noel meets her greeting of "[h]ail!" with the facetious reply "[s]now," 55 Poppy discourages Eugenia from dispensing "justice" on a Pacifist because "we're all much too tired," 56 and the local village beauty Mrs Lace describes the group's involvement with Social Unionism as being "all a joke." ${ }^{, 57}$ Mitford levels her critique at two very different types of political engagement: extremists such as Eugenia (and by extension, Diana and Unity), who take themselves and their politics far too seriously, and those who 
weakly commit to a particular brand of politics without necessarily understanding its loaded implications.

The climax of the novel, a pageant play put on by the Union Jackshirts, is Mitford's most explicit attack on fascists who mask themselves behind a return to tradition. Joshua D. Esty discusses the revival in the 1930s of the pageant play, an invented tradition of the Edwardian era that sought to bring civic cohesion and promote nationalism. ${ }^{58}$ As "putative vessels of folk consciousness," pageant plays strongly embodied rural and traditional ideas of Englishness. ${ }^{59}$ Mitford's comic appropriation of a festive form known for its emphasis on tradition and history devalues fascism's attempts to use what Raymond Williams has described as the "well-known habit of using the past $[\ldots]$ as a stick to beat the present" to its advantage. ${ }^{60}$ Wigs on the Green's pageant play presents fascism not as a serious political undertaking, but as a movement defined by clumsiness, lunacy, and clowning.

While Eugenia wants a pageant focused on the events in the recent history of fascism ("the March on Rome, the Death of Horst Wessel, the Burning of the Reichstag"), Noel wants one focused on a more well-known set of characters reflecting England's history: "Edward I, Florence Nightingale, Good Queen Bess." ${ }^{\prime 61}$ Stuck between a desire to promote political progress and commitment to a version of national history, the group finally compromises by choosing to re-enact George III and Queen Charlotte's visit to Chalford in the eighteenth century, with neighboring village branches of Social Unionists to act out the various key moments of the couple's reign. While George III may initially appear an odd choice, his reign during the eighteenth century makes an appropriate period for a fascist pageant play. The period saw the Agricultural Revolution and a huge rise in rural populations, marking it as a time of prosperity for the countryside — a ready alignment with the Nazi ideals of Volksgemeinschaft and Blut und Boden that sought for a unified and hierarchical society with an innate connection to pastoral land. As Esty suggests, the pageant play collapsed complex 
histories into a "seductive continuity" of Englishness and tradition. ${ }^{62}$ The pageant play in Wigs on the Green illustrates attempts by the fascists to present their principles as an extension of English history. For instance, one episode of the play involves a messenger telling George III that Louis XVI of France "had been razored up by Marxist non-Aryans." 63

Mitford uses George III to further undermine any chance of the reader taking the pageant play seriously. As Jasper tells Eugenia, the only thing that the "ordinary person" knows about George III is that "he went mad and lost America." ${ }^{64}$ His madness thus deflates any attempts to politicize his figure: the speech that Eugenia so earnestly writes for the character in the pageant becomes nothing but inane ramblings. In the speech, George III tells Chalford's subjects of a "prophetic dream" he had where Britain had become "the slush and slime of a decaying democracy," but that Social Unionism will overthrow this decline, leading to "the fulfilment of a Glorious Britain." 65 To attribute such a politically charged speech to a monarch popularly imagined to have mistaken a tree for the King of Prussia during one of his bouts of madness renders it devoid of its intended message.

In staging the pageant, the characters show little regard for historical accuracy. We are told it ignores "historical truth to a degree unprecedented even in pageantry," 66 and indeed, its episodes are staged not as tragedy or triumph, but as bawdy comic relief. Nelson's wounding at the Battle of Santa Cruz de Tenerife presents itself as a circumstance of foolishness and distraction rather than heroism: his arm is "blown off" after having "his telescope pressed to his blind eye, and staring at Lady Hamilton with his other one." ${ }^{\circ 7}$ The scene that follows is a jaunty musical number from the band, the popular song "Ship Ahoy! (All the Nice Girls Love a Sailor)," filled with lyrics such as "[w]ell, you know what sailors are / Bright and breezy, free and easy." Similarly, Nelson's final words before his death at the Battle of Trafalgar — a plea to look after Lady Hamilton — become a childish, rhyming entreaty: "[1]ook after pretty witty Emmie." 68 Transforming such historical moments into 
opportunities for laughter, the pageant play both further illustrates the weak commitments of the characters and undermines any serious political project the Social Unionists may have.

The pageant play culminates with chaos when a group of Pacifists crash the party dressed as the sans-culottes of the French Revolution, marking the fisticuffs that the novel's title alludes to. ${ }^{69}$ But the violence is presented as clumsy, and really, not that violent at all: the Pacifists' weapons range from the unsophisticated and unrefined ("potatoes stuffed with razor blades") to the downright antithetical ("life preservers"). ${ }^{70}$ Yet these weapons prove to be effective against the Social Unionists, as their elaborate costumes leave them comically vulnerable. We are told that "atrocities too horrible to name" take place during the battle and that hardly any Social Unionists escape injury, but there is little sense that these injuries are at all grave. ${ }^{71}$ When the Social Unionists are eventually victorious, they punish the captured Pacifists by forcing them to consume "enormous doses" of laxatives. ${ }^{72}$ Mitford recasts fascist paramilitary violence as being merely uncomfortable and purgative, rather than deadly. ${ }^{73}$

By politicizing the pageant play, Mitford calls attention to the ways in which fascism hijacks tradition to project its ideologies. But while Mitford is willing to poke fun at and critique the very class she belongs to - the aristocracy - her critique is levelled only at their politics, not their values. It is important to acknowledge that Mitford (like Mosley) also harbored a certain nostalgia for the past, the "good old days" when everyone knew their social place, and established families like her own lived in expansive country estates. ${ }^{74}$ What Mitford objects to is the way the aristocracy is so willing to readily engage with radical politics to restore this ideal, without necessarily interrogating the pernicious implications of such politics.

\section{"I don't know a thing about politics": Wigs on the Green's Subversive Comedy}

The inability of the characters to question the politics they have embedded themselves in 
reflects their broader struggles with decision making. Impulse drives the majority of the central cast of characters, and it is their failure to wholly commit that sees them end up in Chalford in the first place. Noel comes into some money and immediately decides to quit his job to search for an heiress to marry instead; Jasper seems to have no obligations to keep him from doing as he pleases, but is terrible with money and relies on others to bankroll his activities; Marjorie has jilted her fiancé only days before the wedding; and Poppy is running away from her husband because he is having an affair with a debutante. Their incapability to sincerely dedicate themselves — whether it be to work, politics, relationships, ideas, or money - gives the novel much of its comic frivolity. In doing so, Mitford positions the aristocracy as unable to judge the radical elements of fascism clearly and objectively.

I want to focus here on the representation of women in the novel and particularly the character of Poppy, as her attitudes typify much of the novel's depiction of weak characters. Easily converted to Social Unionism, Poppy shows herself to have ambivalent views about the role of the modern woman. As Gottlieb illustrates, the vision of women in an established British fascist state was one of domesticity, emphasizing the roles of women as mothers and homemakers. ${ }^{75}$ Eugenia certainly projects these ideas, explaining that "the woman's duty is to retire to her proper place, the bedroom," should "have husbands and great quantities of healthy Aryan children" instead. ${ }^{77}$ Even though she is not as firm in her views as Eugenia, this return to traditional domesticity attracts Poppy to Social Unionism. She admits to not knowing "a thing about politics," but is confident that "Hitler must be a wonderful man" simply because he has "forbidden German women to work in offices and told them they never need worry about anything again, except arranging the flowers." ${ }^{, 78}$ Rather than seeing Social Unionism for what it is—a form of radical politics-Poppy views it as an opportunity to reinforce what she enjoys most: leisure and pleasure. 
Yet Poppy's attitudes are more complex than this. While she accepts the conservative views of fascism, her modern takes on love and marriage mediate fascism's ideology. Poppy's dedication to her marriage (despite her husband's cheating ways) is not out of love, but because she fears not having enough money to live on and buy things with. A conversation between her and Jasper reveals her superficiality: trying to engage her on the topic of nihilism, Jasper tells Poppy that she is like all other women because "you only care about personalities, things don't interest you."79 Poppy's response ("I'm fearfully interested in things - I absolutely long for a sable coat") shows she misreads Jasper's words. While Jasper is using "things" to refer to the abstract and the intellectual, Poppy immediately thinks of "things" in their material form, as objects, revealing her shallowness. ${ }^{80}$ This interest in things qua objects continues throughout the novel. After Jasper's wealthy uncle gifts Poppy a diamond tiara, Jasper is relieved that they will now be able to marry and live off the proceeds of the valuable item, but Poppy sees the item as her possession: "I don't somehow think I intend to sell my tiara." ${ }^{81}$ The only thing that tempts her to return home to her husband is the thought of "her little house in Chapel Street" and its beautiful furniture and décor. ${ }^{82}$ While Poppy claims to not "really approve of marriage," she also sees it to be a necessity, not for love or happiness but because it would be embarrassing to be "called Miss [...] all your life." 83 Through her attitudes towards women, love, and marriage, the novel presents Poppy as an entirely superficial character, from her monolithic interest in material things to her inability to question concepts loaded with deeper meanings and implications.

The characters' triviality is key to understanding Mitford's similarly weak commitment to the conventions of romantic comedy. The novel's ending unites these two areas. After the Social Unionist victory at the pageant play battle, the plot resolves with two romantic pairings: Poppy and Jasper, who plan to marry after Poppy divorces her husband, and Marjorie and Mr Wilkins. In giving the reader these pairings, Mitford follows the 
expected marriage plot, but the novel's ending is by no means a satisfying resolution. As Regina Barreca argues, the endings of works by women writers of comedy are frequently subversive: they either fail to replicate the hierarchies expected of them, or if they do replicate these hierarchies, "there is often an attendant sense of dislocation." ${ }^{84}$ Barreca points to the marriage plot in Jane Austen's Mansfield Park as exemplary of this trend. While Mansfield Park provides the requisite happy ending with the union of Fanny and Edmund, Austen writes it in an entirely superficial manner to indicate her weak commitment to the conventions that regulate her chosen form. ${ }^{85}$

Wigs on the Green presents a similar ending to Mansfield Park. The novel resolves in marriage, but Mitford denies her reader a strong or positive attachment to her characters, or indeed any real sense of these relationships being genuine romantic connections. The novel continually presents the central characters (excepting Eugenia) as insincere and flighty, willing to accept anything providing it benefits them; it is difficult to believe that these characteristics have suddenly evaporated or changed by the novel's conclusion. Throughout the novel we are given the comedy, but not the romance: Marjorie's courtship of Mr Wilkins largely takes place off the page, and Poppy eventually acquiesces to Jasper's pleas for them to marry on the basis that "[i]t would seem a bit wasteful not to keep you about the place." The novel's structure further suggests Mitford's resistance to providing a satisfying ending. After the pageant play battle, the novel's final chapter jumps forward several months to Marjorie and Mr Wilkins's wedding reception in London, only to gloss over it quickly. Moreover, given the sheer number of potential pairings the novel presents - Noel and Jasper spend copious amounts of time debating whether they should be chasing Eugenia, Poppy, Marjorie, or Mrs Lace - the romantic connections seem tenuous at best. There is little confidence that Marjorie and Mr Wilkins's marriage will last: at the wedding, Marjorie's mother resigns herself to the coupling, consoling herself that “[p]oor Mr Wilkins [...] doesn't 
want to marry her in the least" and that "divorce is such an easy matter in these days." ${ }^{87}$ As Allan Hepburn has noted, love and marriage are not the same in Mitford's novels, as the former is not a requirement for the latter to take place. ${ }^{88}$ Marriage in Wigs in the Green is a necessity due to its genre, but its sincerity and longevity are questionable.

For Barreca, women's comedy is concerned with "de-centering, dislocating and destabilising"-it subverts and refuses closure. ${ }^{89}$ By the conclusion of Wigs on the Green, there is little sense that any of the characters have changed for the better, and Social Unionism still reigns over the aristocracy, as the guests at the wedding reception sing the Union Jackshirts' anthem as a tribute to the couple. For Suh, Mitford's critique of fascism is "deeply ambiguous" due to the novel's combination of both "satire and elegy." 90 But by providing a mere perfunctory gesture towards the narrative conclusion that governs its form, the novel's ending serves to reinforce Mitford's anti-fascist project. In creating an ending where the reader is neither attached to the characters or the romantic relationships between them, Mitford deliberately transfigures what should be a satisfying resolution into a thoroughly unsatisfying one. The novel ends exactly how it begins. Noel is back working in a bank, repeating the same words spoken on the first page: "[n]o, I'm sorry, [...] not sufficiently attractive. ${ }^{" 91}$ With its characters trapped in a loop without room for growth or progress, the novel's ending feels resolutely bleak, even with its (supposedly) celebratory tone.

This claim is upheld when comparing Wigs on the Green to Mitford's other novels, which are similarly characterized by their speedy and disconcerting resolutions of plot, especially in relation to love and marriage. In Highland Fling, a frivolous Bright Young Thing attempts to call off her engagement via a letter to her fiancé but goes ahead with the marriage when the letter goes unseen; in Christmas Pudding, the heroine is left heartbroken by one man and quickly marries another whom she does not love instead. In The Pursuit of Love, Linda Radlett finally finds love after two failed marriages only to die in childbirth, and 
her lover Fabrice is killed in the Second World War, yet this tragic turn of events receives only a cursory reference in the novel's closing paragraphs. ${ }^{92}$ Likewise, in its sequel, Love in a Cold Climate, the breakdown of the scandalous marriage between debutante Polly Hampton and her lecherous uncle, Boy Dougdale, is effortlessly smoothed over in the final lines, with Cedric Hampton taking Boy to Paris, leaving Polly free to pursue a relationship with an elderly duke. ${ }^{93}$

While Blanch argues that in women's writing of the interwar period, humor acts to discharge anxieties about gender and class, ${ }^{94}$ Wigs on the Green actively goes against this claim. As Berlant and Ngai point out, comedy — theorized by Freud to release anxiety — often works to create it instead. ${ }^{95}$ Mitford's weak commitment to the conventions of her chosen mode produces anxiety, creating the unsettling ending to the novel. Rather than bringing restorative relief, Mitford presents uneasiness and uncertainty, a dystopian vista where radicalism blindly consumes the aristocracy. For Lisa Colletta, social comedies like Mitford's have a "certain comedic ambivalence," making them "much less conservative than is generally assumed." ${ }^{96}$ In Hélène Cixous and Catherine Clément's words, “all laughter is allied with the monstrous," 97 and in its subversiveness, the comedy of Wigs on the Green is dangerous.

\section{Conclusion}

For Mitford's characters, there is no other apparent answer to their concerns but Social Unionism. Their flippant attitudes render them unable to see beyond what is directly in front of them: while they initially commit to the movement with little consideration, by the novel's end, they are in too deep to escape. This inability to separate values from politics becomes Mitford's object of critique in Wigs on the Green. While Mitford herself shares many of the aristocratic concerns that the characters articulate, she argues that extremism is not the 
answer to resolving them. Weak commitments—-both in the novel's form and contentprovide the basis for this comic critique. Intermodernism, a framework acutely attuned to weakness, offers a means by which to read, negotiate, and better understand Mitford's work, as well as other women writers of comedy in the interwar, war, and postwar periods. In presenting the aristocracy's fascist sympathies as an opportunity for subversive comic commentary, Wigs on the Green enriches our understanding of how fascism and Nazism were understood and presented by intermodern women writers.

\section{Notes}

1. Mitford, Love from Nancy, 70.

2. Ibid., 70 .

3. Ibid., 66.

4. Ibid., 68-69.

5. Mitford, Wigs on the Green, 13.

6. Mitford, Love from Nancy, 63.

7. Mitford, Wigs on the Green, 35.

8. Hastings, Nancy Mitford, 104.

9. Straus, "Problems of Private Life," 9.

10. Mitford and Waugh, The Letters of Nancy Mitford and Evelyn Waugh, 249. The Popular Library republished Wigs on the Green in a two-in-one volume alongside Highland Fling in 1976. The novel then remained out of print for more than thirty years before Penguin republished it in 2010, as part of a reissue of all Mitford's novels.

11. Berlant and Ngai, "Comedy Has Issues," 234.

12. See, for example, Sherry, Ezra Pound, Wyndham Lewis, and Radical Modernism; and Surette, Dreams of a Totalitarian Utopia.

13. Berman, Modernist Fiction, Cosmopolitanism, and the Politics of Community; Carlston, Thinking Fascism; Frost, Sex Drives; and Pawlowski, ed., Virginia Woolf and Fascism.

14. Suh, Fascism and Anti-Fascism, 1.

15. This tendency toward ambivalence was rife in Mitford's personal circle, as Beci Carver's research on "chucking" in the work of Evelyn Waugh has shown. Carver, "Chucking in Evelyn Waugh," 897.

16. Bluemel, "Not Waving or Drowning," 67.

17. Saint-Amour, "Weak Theory, Weak Modernism," 439. Saint-Amour's discussion of the weak draws primarily upon Wai Chee Dimock, Eve Kosofsky Sedgwick, and Gianni Vattimo. However, Saint-Amour's ideas also speak to a significant body of foundational feminist and queer scholarship (which has long been interested in matters of weakness, failure, disappointment, and the low) beyond Sedgwick. See, for example: Ahmed, Queer Phenomenology; Berlant, Cruel Optimism; Butler, Gender Trouble; Cvetkovich, An Archive of Feelings; Halberstam, The Queer Art of Failure; and Love, Feeling Backward.

18. Ibid., 451.

19. Bluemel, "Introduction: What Is Intermodernism?," 11.

20. Saint-Amour, Tense Future, 23.

21. Bluemel and Lassner, "Feminist Inter/Modernist Studies," 25.

22. Bluemel, "Introduction: What Is Intermodernism?," 2.

23. Bluemel and Lassner, "Feminist Inter/Modernist Studies," 23. 
24. Saint-Amour, Tense Future, 33.

25. Bluemel, "Exemplary Intermodernists," 42.

26. Bluemel and Lassner, "Feminist Inter/Modernist Studies," 24.

27. Mao and Walkowitz, "The New Modernist Studies," 737.

28. Hammill, "Afterword," 231.

29. Bluemel and Lassner, "Feminist Inter/Modernist Studies," 23.

30. Blanch, "Women and Comedy," 112.

31. Macdonald, "Comic Short Fiction," 145.

32. Brown, Comedy and the Feminine Middlebrow Novel, 17.

33. For example, Lisa Colletta argues "[d]ark humor is characterized by the very concerns of Modernism," while Jonathan Greenberg sees satire as "a way of thinking, feeling, and writing central to modernism." Likewise, Tyrus Miller places emphasis on satire, parody, and the grotesque for generating late modernism's "self-reflexive laughter," which "bursts out $[\ldots]$ at moments of maximum stress on characters, pushed to the limits of madness, dissociation, and death." Colletta, Dark Humor and Social Satire, 2; Greenberg, Modernism, Satire and the Novel, 2; and Miller, Late Modernism, 57.

34. Hastings, Nancy Mitford, 129.

35. Gottlieb, "Women and British Fascism," 111.

36. Mitford, Wigs on the Green, 9.

37. Gottlieb, Feminine Fascism, 197.

38. Suh, Fascism and Anti-Fascism, 133.

39. Gottlieb, Feminine Fascism, 177.

40. Cannadine, The Decline and Fall of the British Aristocracy, 548-49.

41. Mitford, Wigs on the Green, 9.

42. Bluemel, "Introduction: What Is Intermodernism?," 12.

43. Brace, "Finding England Everywhere," 90-91.

44. Matless, Landscape and Englishness, 25.

45. Gottlieb, Feminine Fascism, 198.

46. Griffiths, Fellow Travellers of the Right, 168.

47. Mosley, The Mitfords, 34.

48. Bluemel and Lassner, "Feminist Inter/Modernist Studies," 27.

49. Mitford, Wigs on the Green, 7.

50. Ibid.

51. Ibid., 113.

52. Ibid., 10.

53. Ibid., 11.

54. Ibid., 89.

55. Ibid., 34.

56. Ibid., 75.

57. Ibid., 78.

58. Esty, "Amnesia in the Fields," 247.

59. Ibid., 246-47.

60. Williams, The Country and the City, 12.

61. Mitford, Wigs on the Green, 46.

62. Esty, "Amnesia in the Fields," 249.

63. Mitford, Wigs on the Green, 155.

64. Ibid., 88.

65. Ibid.

66. Ibid., 155.

67. Ibid., 152.

68. Ibid., 153.

69. Given the full eighteenth-century costumes worn by the Social Unionists (including powdered wigs) and the pageant play's setting (a country estate), the meaning of the novel's title is literal: during the battle, there really are wigs on the green. There is also a verbal pun at play here, with "wigs" being a homophone for "Whigs." 
70. Mitford, Wigs on the Green, 157.

71. Ibid., 157.

72. Ibid., 159.

73. Mitford was witness to the Blackshirts' violence at one of the few BUF meetings she attended in late 1933. She wrote to Diana (with her typical lightness and a touch of mockery): "[t]here were several fascinating fights, as he [Mosley] brought a few Neanderthal men along with him \& they fell tooth \& (literally) nail on anyone who shifted his chair or coughed. One man complained afterwards that the fascists' nails had pierced his head to the skull." Mitford, Love from Nancy, 62 (emphasis in original).

74. Hastings, Nancy Mitford, 113, 224.

75. Gottlieb, Feminine Fascism, 101.

76. Mitford, Wigs on the Green, 89.

77. Ibid., 36-37.

78. Ibid., 37.

79. Ibid., 99.

80. Ibid.

81. Ibid., 134.

82. Ibid., 146.

83. Ibid., 127.

84. Barreca, Untamed and Unabashed, 24.

85. Ibid.

86. Mitford, Wigs on the Green, 161.

87. Ibid., 167.

88. Hepburn, "The Fate of the Modern Mistress," 340.

89. Barreca, Untamed and Unabashed, 30.

90. Suh, Fascism and Anti-Fascism, 134-35.

91. Mitford, Wigs on the Green, 170.

92. "On the 28th May both our babies were born - both boys. The doctors who said that Linda ought never to have another child were not such idiots after all. It killed her. [...] At about the same time as Linda's death Fabrice was caught by the Gestapo and subsequently shot." Mitford, The Pursuit of Love, 194-95.

93. "Cedric managed the whole thing quite beautifully. As soon as Polly had completely recovered her health and looks, he put Lady Montdore and Boy into the big Daimler and rolled away with them to France. The field was thus left to a Morris Cowley which, sure enough, could be seen day after day in the drive at Silkin. Before very long, Polly got into it and was taken to Paddington Park, where she remained." Mitford, Love in a Cold Climate, 249.

94. Blanch, "Women and Comedy," 114.

95. Berlant and Ngai, "Comedy Has Issues," 233.

96. Colletta, Dark Humor and Social Satire, 12.

97. Cixous and Clément, The Newly Born Woman, 33. 


\section{Bibliography}

Ahmed, Sara. Queer Phenomenology: Orientations, Objects, Others. Durham, NC: Duke University Press, 2006.

Barreca, Regina. Untamed and Unabashed: Essays on Women and Humor in British Literature. Detroit: Wayne State University Press, 1994.

Berlant, Lauren. Cruel Optimism. Durham, NC: Duke University Press, 2011.

Berlant, Lauren, and Sianne Ngai. “Comedy Has Issues.” Critical Inquiry 43, no. 2 (2017): 233-49. doi:10.1086/689666.

Berman, Jessica. Modernist Fiction, Cosmopolitanism, and the Politics of Community. Cambridge: Cambridge University Press, 2001.

Blanch, Sophie. "Women and Comedy." In The History of British Women's Writing, 1920 1945, edited by Maroula Joannou, 112-28. Basingstoke: Palgrave Macmillan, 2012. Bluemel, Kristin. "Exemplary Intermodernists: Stevie Smith, Inez Holden, Betty Miller, and Naomi Mitchison.” In The History of British Women's Writing, 1920-1945, edited by Maroula Joannou, 40-56. Basingstoke: Palgrave Macmillan, 2012.

Bluemel, Kristin. “Introduction: What is Intermodernism?" In Intermodernism: Literary Culture in Mid-Twentieth-Century Britain, edited by Kristin Bluemel, 1-18. Edinburgh: Edinburgh University Press, 2011.

Bluemel, Kristin. "Not Waving or Drowning: Refusing Critical Options, Rewriting Literary History." In And in Our Time: Vision, Revision, and British Writing of the 1930s, edited by Antony Shuttleworth, 65-94. Lewisburg: Bucknell University Press, 2003.

Bluemel, Kristin, and Phyllis Lassner. "Feminist Inter/Modernist Studies." Feminist Modernist Studies 1, no. 1-2 (2018): 22-35. doi:10.1080/24692921.2017.1380777.

Brace, Catherine. "Finding England Everywhere: Regional Identity and the Construction of National Identity, 1890-1940.” Ecumene 6, no. 1 (1999): 90-109. doi:10.1177/096746089900600105.

Brown, Erica. Comedy and the Feminine Middlebrow Novel: Elizabeth von Arnim and Elizabeth Taylor. London: Pickering and Chatto, 2013.

Butler, Judith. Gender Trouble: Feminism and the Subversion of Identity. New York: Routledge, 2011.

Cannadine, David. The Decline and Fall of the British Aristocracy. New Haven: Yale University Press, 1990. 
Carlston, Erin G. Thinking Fascism: Sapphic Modernism and Fascist Modernity. Stanford: Stanford University Press, 1998.

Carver, Beci. “Chucking in Evelyn Waugh.” Textual Practice 32, no. 5 (May 28, 2018): 895912. doi:10.1080/0950236X.2016.1275760.

Cixous, Hélène, and Catherine Clément. The Newly Born Woman. Translated by Betsy Wing. Minneapolis: University of Minnesota Press, 1986.

Colletta, Lisa. Dark Humor and Social Satire in the Modern British Novel. Basingstoke: Palgrave Macmillan, 2003.

Cvetkovich, Ann. An Archive of Feelings: Trauma, Sexuality, and Lesbian Public Cultures. Durham, NC: Duke University Press, 2003.

Esty, Joshua D. “Amnesia in the Fields: Late Modernism, Late Imperialism, and the English Pageant-Play." ELH 69, no. 1 (2002): 245-76. doi:10.1353/elh.2002.0003.

Frost, Laura. Sex Drives: Fantasies of Fascism in Literary Modernism. Ithaca: Cornell University Press, 2002.

Gottlieb, Julie V. Feminine Fascism: Women in Britain's Fascist Movement. London: Tauris, 2003.

Gottlieb, Julie V. "Women and British Fascism Revisited: Gender, the Far-Right, and Resistance." Journal of Women's History 16, no. 3 (2004): 108-23. doi:10.1353/jowh.2004.0065.

Greenberg, Jonathan. Modernism, Satire, and the Novel. Cambridge: Cambridge University Press, 2011.

Griffiths, Richard M. Fellow Travellers of the Right: British Enthusiasts for Nazi Germany, 1933-9. London: Constable, 1980.

Halberstam, Jack. The Queer Art of Failure. Durham, NC: Duke University Press, 2011. Hammill, Faye. “Afterword.” In Middlebrow Literary Cultures: The Battle of the Brows, 1920-1960, edited by Erica Brown and Mary Grover, 231-33. Basingstoke: Palgrave Macmillan, 2012.

Hastings, Selina. Nancy Mitford: A Biography. London: Hamilton, 1985.

Hepburn, Allan. "The Fate of the Modern Mistress: Nancy Mitford and the Comedy of Marriage." Modern Fiction Studies 45, no. 2 (1999): 340-68. doi:10.1353/mfs.1999.0039.

Love, Heather. Feeling Backward: Loss and the Politics of Queer History. Cambridge, MA: Harvard University Press, 2009. 
Mao, Douglas, and Rebecca L. Walkowitz. "The New Modernist Studies.” PMLA 123, no. 3 (2008): 737-48. doi:10.1632/pmla.2008.123.3.737.

Macdonald, Kate. "Comic Short Fiction and Its Variety." In The Cambridge Companion to the English Short Story, edited by Ann-Marie Einhaus, 145-58. New York: Cambridge University Press, 2016.

Matless, David. Landscape and Englishness. London: Reaktion, 1998.

Miller, Tyrus. Late Modernism: Politics, Fiction, and the Arts Between the World Wars. Berkeley: University of California Press, 1999.

Mitford, Nancy. Love from Nancy: The Letters of Nancy Mitford. Edited by Charlotte Mosley. London: Hodder and Stoughton, 1993.

Mitford, Nancy. Love in a Cold Climate. 1949. Reprint, Camberwell: Penguin, 2008.

Mitford, Nancy. The Pursuit of Love. 1945. Reprint, London: Hamish Hamilton, 1946.

Mitford, Nancy. Wigs on the Green. 1935. Reprint, London: Penguin, 2016.

Mitford, Nancy, and Evelyn Waugh. The Letters of Nancy Mitford and Evelyn Waugh. Edited by Charlotte Mosley. London: Hodder and Stoughton, 1996.

Mosley, Charlotte, ed. The Mitfords: Letters Between Six Sisters. London: Harper Perennial, 2008.

Pawlowski, Merry M., ed. Virginia Woolf and Fascism: Resisting the Dictators'Seduction. Basingstoke: Palgrave Macmillan, 2001.

Saint-Amour, Paul K. Tense Future: Modernism, Total War, Encyclopedic Form. Oxford: Oxford University Press, 2015.

Saint-Amour, Paul K. "Weak Theory, Weak Modernism.” Modernism/modernity 25, no. 3 (2018): 437-59. doi:10.1353/mod.2018.0035.

Sherry, Vincent. Ezra Pound, Wyndham Lewis, and Radical Modernism. Oxford: Oxford University Press, 1993.

Straus, Ralph. "Problems of Private Life and a Fantasy for Dog-Lovers." Sunday Times. June 30, 1935.

Suh, Judy. Fascism and Anti-Fascism in Twentieth-Century British Fiction. New York: Palgrave Macmillan, 2009.

Surette, Leon. Dreams of a Totalitarian Utopia: Literary Modernism and Politics. Montreal: McGill-Queen's Press, 2011.

Williams, Raymond. The Country and the City. London: Chatto and Windus, 1973. 